\title{
Leptin Responsiveness of Mice Deficient in Corticotrophin-Releasing Hormone Receptor Type 2
}

\author{
Ruth B.S. Harris \\ Department of Foods and Nutrition, University of Georgia, Athens, Ga., USA
}

\section{Key Words}

Food intake $\cdot$ Body weight $\cdot$ Body composition $\cdot$ Gender

\begin{abstract}
Leptin acts centrally to inhibit food intake and increase energy expenditure. Corticotrophin-releasing hormone (CRH) is one of the neuropeptides that may contribute to leptininduced hypophagia and thermogenesis. Acute leptin administration increases CRH mRNA expression in the paraventricular nucleus of the hypothalamus and $\mathrm{CRH}$ receptor type 2 (CRHR2) expression in the ventromedial nucleus of the hypothalamus. Studies described here used male and female CRHR2 knockout (KO) mice and wild-type (WT) controls to test the importance of CRHR2 in mediating the effects of leptin on food intake, weight gain and body composition. Peripheral injections of $0.5 \mathrm{mg} / \mathrm{kg}$ leptin for 3 days inhibited food intake in female WT and male KO mice, but inhibited weight gain in female KO and male WT mice suggesting an important role for thermogenesis in mediating weight loss. A single third ventricle injection of $1 \mu \mathrm{g}$ leptin inhibited $12 \mathrm{~h}$ food intake of all mice, $36 \mathrm{~h}$ cumulative intake of $\mathrm{KO}$ mice and weight loss in WT and KO female and WT male mice. A 12-day peripheral infusion of $10 \mu \mathrm{g}$ leptin/day had no effect on food intake of any group, but significantly reduced carcass fat and protein content of all mice. These results indicate that CRHR2 are not essential for the effects of leptin on food intake, body
\end{abstract}

weight or body composition. Leptin response seems to be determined by a combination of mouse gender and genotype, but CRHR2 KO mice may have an extended response to central leptin injections compared with their WT controls.

Copyright $\odot 2010$ S. Karger AG, Basel

\section{Introduction}

Leptin, an adipose-derived protein, may function as a feedback signal in the regulation of energy balance by acting centrally to inhibit food intake and increase energy expenditure in conditions of increased adiposity [1]. It is thought that leptin inhibits feeding by down-regulating expression of orexigenic neuropeptides and increasing expression of anorexigenic neuropeptides in areas of the hypothalamus associated with the regulation of energy balance $[2,3]$. There are multiple isoforms of the leptin receptor, but only one has a long intracellular domain that includes multiple phosphorylation sites capable of initiating different signaling pathways [4]. These receptors are present at a relatively high concentration in the hypothalamus [5] and brainstem [6] and have recently been identified in the mid-brain [7]. Within the hypothalamus, long-form leptin receptors have been identified in the arcuate (ARC), paraventricular (PVN), ventromedial (VMH) and lateral nuclei [5].

\section{KARGER}

Fax +4161306 1234

E-Mail karger@karger.ch

www.karger.com (c) 2010 S. Karger AG, Basel

Accessible online at: www.karger.com/nen
Ruth Harris

Physiology Department, CA 1020, Medical College of Georgia

112015 th Street, Augusta, GA 30912 (USA)

Tel. +1 706721 4479, Fax +1 7067217299

E-Mail ruharris@mcg.edu 
Corticotrophin-releasing hormone $(\mathrm{CRH})$ is a primary mediator of stress responses, including inhibition of food intake [8] and increased energy expenditure [9]. Both in vivo and in vitro studies have shown that leptin administration increases expression of CRH in the PVN [10-13]. There are two major subtypes of the CRH receptor: type 1 (CRHR1) and type 2 (CRHR2). CRHR2 are anxiolytic, are involved in the development of passive coping strategies in response to repeated or extended exposure to stress and mediate a delayed anorexia in conditions of stress [14]. Within the hypothalamus, CRHR2 are present at high concentrations in the $\mathrm{VMH}$ and low concentrations in the PVN $[15,16]$.

There is evidence that leptin and corticosterone show opposing diurnal changes in release [17] and that leptin can contribute to the regulation of stress-induced activation of the hypothalamic pituitary adrenal (HPA) axis in leptin-deficient ob/ob mice [18]. Independent of these leptin- $\mathrm{CRH}$ interactions are reports that $\mathrm{CRH}$ may be at least partially responsible for the central actions of leptin that lead to a suppression of food intake. Third ventricle injections of leptin stimulate PVN CRH mRNA [10], increase hypothalamic CRH content [19] and inhibit ARC neuropeptide $\mathrm{Y}$ mRNA expression in fasted rats [10]. These changes in CRH were not associated with increases in circulating corticosterone concentrations, indicating activation of a CRH-related pathway that was independent of stimulation of the HPA axis. Simultaneous injections of leptin and a non-specific $\mathrm{CRH}$ receptor antagonist confirmed that $\mathrm{CRH}$ is involved in the mediation of acute leptin-induced anorexia $[19,20]$. In efforts to identify the $\mathrm{CRH}$ receptor responsible for potential leptin-induced changes in CRH activity, Huang et al. [11] reported that chronic intracerebroventricular infusion of leptin inhibited stress-induced expression of CRHR1, but increased VMH expression of CRHR2. Similarly, Makino et al. [21] reported a positive correlation between plasma leptin concentrations and VMH CRHR2 concentration in rats subjected to different energetic conditions. In a subsequent study the same group reported that single injections of leptin increased both PVN $\mathrm{CRH}$ and VMH CRHR2 mRNA expression, whereas continuous infusions of low doses of leptin increased only the VMH CRHR2 mRNA expression [12]. These low-dose chronic infusions are more representative of physiological concentrations of leptin and because CRH has a low affinity for CRHR2, it is likely that the ligand for CRHR2 receptors in the VMH is one of the urocortins that are $\mathrm{CRH}$ homologues with a high affinity for CRHR2 [22-24].

Leptin and the Requirement for $\mathrm{CRH}$ Receptors
The objective of studies described here was to test the importance of CRHR2 in mediating the effects of leptin on food intake, body weight and body composition using CRHR2 knockout (KO) mice. The responses to acute peripheral and central administration of leptin in addition to chronic peripheral infusion were tested in both male and female wild-type (WT) and CRHR2 KO mice.

\section{Methods}

All of the mice used in studies described here were bred from a colony of CRHR2 KO mice maintained at the University of Georgia. The founders for this colony were a generous gift from Dr. Tracey Bale, University of Pennsylvania, and they were crossed with C57BL/6 mice obtained from Harlan Sprague Dawley (Harlan Laboratories Inc., Indianapolis, Ind., USA). Mice used in this study were from the F6 generation. Heterozygotes were bred and the pups were genotyped at 10 days of age, as described previously [25]. Male and female KO and WT littermates aged 40 days were included in the experiments. No more than 2 male and $2 \mathrm{fe}-$ male $\mathrm{KO}$ and/or 2 male and 2 female WT mice from one litter were included in Experiments 1 and 2 where all animals were tested with each treatment. Only $1 \mathrm{KO}$ and/or $1 \mathrm{WT}$ mouse from each litter was included in a treatment group for Experiment 3 in which animals were assigned to a specific treatment group. The mice were housed in a temperature- and humidity-controlled room $\left(23^{\circ} \mathrm{C}, 55 \%\right.$ humidity) with lights on $12 \mathrm{~h} /$ day from $07: 00 \mathrm{~h}$. The mice were housed individually in shoebox cages fitted with a grid floor to allow measurement of food intake corrected for spillage. A 3-inch length of 1.5-inch diameter plastic tubing was also placed in each cage so that the mice could move off the grid. The mice had free access to chow (Mouse Chow 5012; PMI International, Brentwood, Mo., USA) and water throughout each study, unless specified otherwise. All procedures were approved by the Institutional Animal Care and Use Committee of the University of Georgia.

\section{Experiment 1: Response to Peripheral Injections of Leptin}

The objective of this study was to determine the sensitivity of the different genotypes of mice to peripherally administered leptin. 8 male and 8 female KO and 8 male and 8 female WT mice were adapted to cages with grid floors for 3 days. They were weighed daily to familiarize them with handling for 5 days. On day 6 the mice were weighed and food was removed from the cages at 08:00 h. Starting at 18:00 h, each mouse was injected intraperitoneally with $0,0.5,1.0$ or $2.0 \mathrm{mg} / \mathrm{kg}$ leptin (recombinant mouse leptin; R\&D Systems, Minneapolis, Minn., USA) in a volume of $0.1 \mathrm{ml}$ per $10 \mathrm{~g}$ body weight. The mice were assigned to a dose in random order. Food was returned to the cages at 19:00 h. The mice were food-deprived during the day and injected with the same dose of leptin at 18:00 h on each of the subsequent 2 days and body weights and food intakes were recorded each morning $(12,36,60 \mathrm{~h}$ after the first injection). After a 5-day washout period, the 3-day test was repeated until each mouse had been tested with each dose of leptin. The mice were food deprived for $11 \mathrm{~h}$ before each injection in order to ensure that they all were hungry and to optimize conditions for detecting an inhibitory effect of 
leptin on food intake. Because mice consume only $25 \%$ of their daily food during the light phase [26], this deprivation is unlikely to have caused a substantial level of stress in the animals.

Experiment 2: Response to Third Ventricle Injections of Leptin The previous study showed both sex and genotype differences in leptin responsiveness. The objective of this study was to test whether these differences were sustained when leptin was administered centrally. 11 male WT, 11 male KO, 11 female WT and 11 female $\mathrm{KO}$ mice were included in this experiment. The mice were fitted with third ventricle cannulas as described previously [27]. The viability of each cannula was tested by measuring $2 \mathrm{~h}$ food intake of fed mice infused with $4 \mu \mathrm{g}$ NPY (Sigma Chemical Co., St. Louis, Mo., USA) at 08:00 h. Animals that ate $0.5 \mathrm{~g}$ or more ( $\sim 25 \%$ of their normal daily intake) in $2 \mathrm{~h}$ were included in the experiment. 11 male WT, 11 male KO, 10 female WT and 8 female $\mathrm{KO}$ mice were included in the study. One week after testing cannula placement, food was removed from the cages at 07:00 h. Starting at 17:30 h, each mouse received a third ventricle injection of either sterile PBS or $1.0 \mu \mathrm{g}$ leptin injected in a volume of $2 \mu \mathrm{l}$ over 1 min using a Hamilton infusion pump. The dose of leptin was the same as we previously used to test central leptin responsiveness of $\mathrm{C} 57 \mathrm{BL} / 6$ mice [27]. Food was returned to the cages at 18:30 h and food intakes and body weights were measured in the morning of the 2 next days ( 12 and $36 \mathrm{~h}$ after injection). One week later the experiment was repeated and the animals that had received PBS during the first test were infused with leptin and those that had been tested with leptin were infused with PBS.

\section{Experiment 3: Response to Peripheral Infusions of Leptin}

This study tested the effect of chronically administered physiological doses of leptin on body composition of the different genotypes of mice. 16 male WT, 12 male KO, 16 female WT and 16 female $\mathrm{KO}$ mice were included in this study. The mice were adapted to the cages with grid floors for 2 days. Baseline daily food intake and body weight were recorded for 5 days and then the mice were weight matched within sex and genotype into two groups. Each mouse was fitted with an intraperitoneal Alzet miniosmotic pump (Model 1002; Durect Corp., Cupertino, Calif., USA) delivering either PBS or $10 \mu \mathrm{g}$ leptin/day in a volume of $0.25 \mu \mathrm{l} / \mathrm{h}$. Daily weights and food intakes were recorded for a further 12 days and then the mice were sacrificed for determination of body composition. The mice were decapitated and trunk blood was collected for measurement of serum leptin concentrations (Multispecies Leptin RIA kit; MP Biomedicals, Solon, Ohio, USA). Inguinal, retroperitoneal, epididymal and mesenteric fat depots were dissected, weighed and returned to the carcass. Carcass composition was determined as described previously [28].

\section{Statistical Analysis}

Single end-point measures were compared by analysis of variance. Dependent variables were sex, genotype, and leptin. The results of the dose response study and the body weights and food intakes of the animals in the peripheral infusion study were compared by repeated measures analysis of variance. Differences between specific treatment groups were compared by post hoc Duncan's multiple range test and $\mathrm{p}<0.05$ was considered significant. All statistical comparisons were made using Statistica Software (StatSoft, Inc., Tulsa, Okla., USA).
Table 1. Cumulative food intake of mice in Experiment 1

\begin{tabular}{llll}
\hline & $12 \mathrm{~h}$ & $36 \mathrm{~h}$ & $60 \mathrm{~h}$ \\
\hline $\begin{array}{lll}\text { Females } \\
\text { WT saline }\end{array}$ & $4.0 \pm 0.1$ & $7.8 \pm 0.2$ & $11.9 \pm 0.3$ \\
WT leptin & $3.3 \pm 0.2$ & $7.0 \pm 0.3$ & $11.2 \pm 0.4$ \\
KO saline & $3.8 \pm 0.15$ & $7.7 \pm 0.3$ & $11.9 \pm 0.5$ \\
KO leptin & $3.3 \pm 0.2$ & $6.2 \pm 0.4^{*}$ & $9.9 \pm 0.5^{*}$ \\
Males & & & \\
WT saline & $4.0 \pm 0.3$ & $7.9 \pm 0.4$ & $11.8 \pm 0.5$ \\
WT leptin & $3.2 \pm 0.4$ & $6.8 \pm 0.3^{*}$ & $10.6 \pm 0.3$ \\
KO saline & $3.8 \pm 0.1$ & $7.6 \pm 0.2$ & $12.4 \pm 0.7$ \\
KO leptin & $3.5 \pm 0.2$ & $6.8 \pm 0.3$ & $10.2 \pm 0.6^{*}$ \\
\hline
\end{tabular}

Cumulative food intake (g/mouse) of mice in Experiment 1. Data are means \pm SEM for groups of 8 mice.

* Time points for which there was a significant difference $(\mathrm{p}<$ $0.05)$ in intake of leptin-treated mice compared with saline-injected controls of the same sex and genotype.

\section{Results}

\section{Experiment 1}

This study measured the food intake and body weights of mice injected peripherally each day for 3 days with increasing doses of leptin. Analysis of data for all of the doses tested indicated that the response to the highest dose of leptin was not different from that to the lowest dose of leptin for any of the groups. Therefore, only the data for the injections of saline and the lowest dose of leptin $(0.5 \mathrm{mg} / \mathrm{kg})$ are shown in figure 1 . Comparisons of body weight change from baseline, measured in the morning before the first of the three injections, showed a significant effect of leptin $(p<0.0001)$ and a significant interaction between genotype and leptin $(\mathrm{p}<0.04)$. Post hoc comparisons showed that female $\mathrm{KO}$, but not female WT mice lost weight in response to leptin injection. By contrast, male WT, but not male KO mice lost weight. When cumulative food intakes of the mice up to $60 \mathrm{~h}$ after the first injection (table 1) were compared for all mice there was a significant effect of leptin $(\mathrm{p}<0.0001)$ and time $(\mathrm{p}<0.0001)$ on intake and there also was an interaction between leptin and time $(\mathrm{p}<0.0002)$. Post hoc analysis intake showed that leptin injections significantly inhibited the food intake of female WT at both 36 and $60 \mathrm{~h}$, of male WT mice at $36 \mathrm{~h}$ and of male $\mathrm{KO}$ mice at $60 \mathrm{~h}$. It should be noted that neither WT female nor KO male mice lost weight in response to leptin injection. 
Fig. 1. Body weight expressed as a percentage of baseline weight (line graphs) and $60 \mathrm{~h}$ food intake (bar graph) of mice that received intraperitoneal injections of 0.5 $\mathrm{mg} / \mathrm{kg}$ leptin or an equivalent volume of saline each day for 3 days in Experiment 1. Data are means \pm SEM for groups of 8 mice. ${ }^{*}$ Differences in weight gain of saline- and leptin-treated mice of a specific sex and genotype. Bars in the graph of food intake that do not share a common superscript are significantly different at $\mathrm{p}<0.05$.

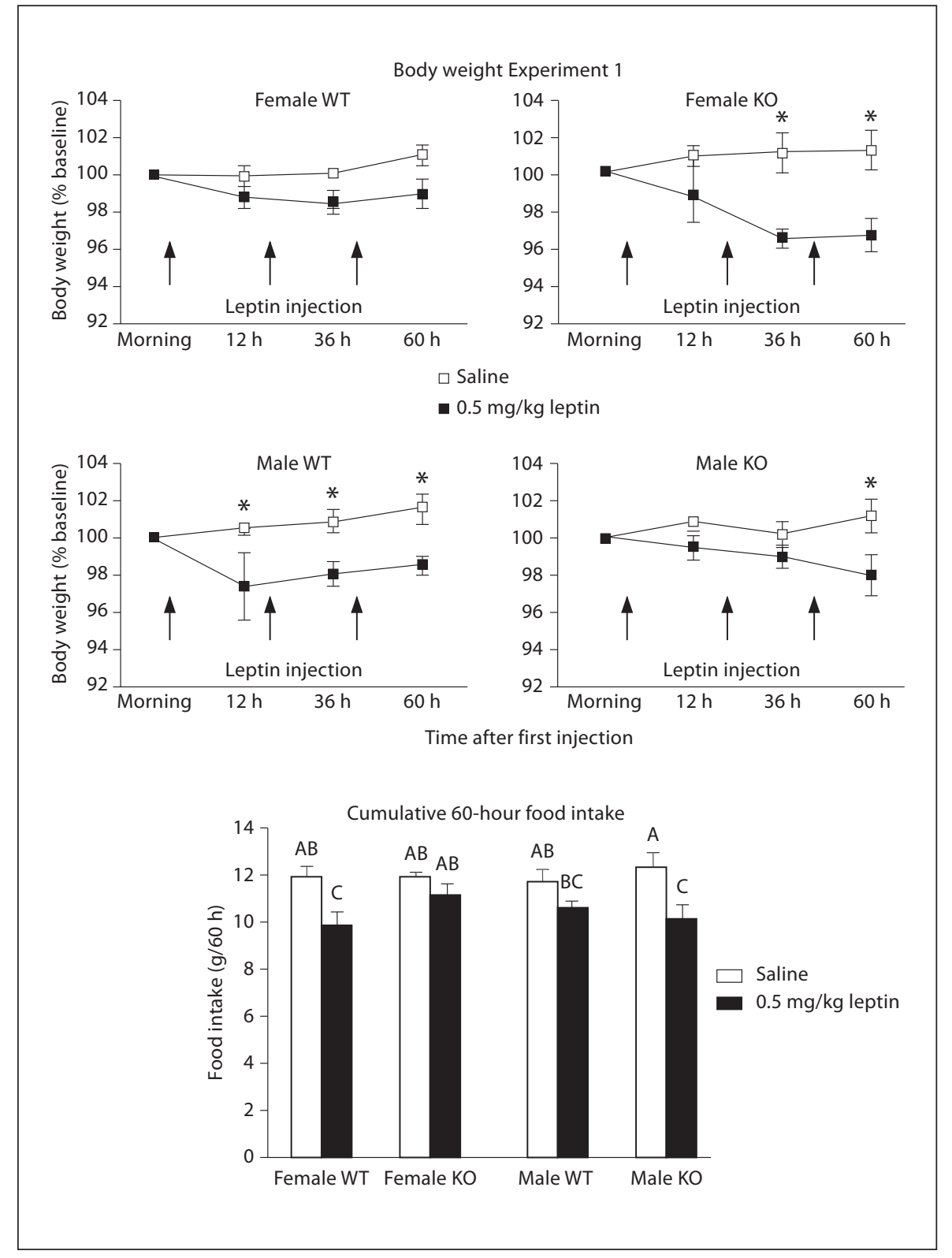

\section{Experiment 2}

This study tested the effects of a single third ventricle dose of leptin on food intake and body weight of the mice. Leptin reduced body weight of all mice, expressed as a percentage of their weight on the morning before the injection (fig. 2: sex: NS, gene: NS, leptin: $\mathrm{p}<0.0001$, time: $\mathrm{p}<0.04$, leptin $\times$ time: $\mathrm{p}<0.03$ ). In male $\mathrm{KO}$ mice the inhibition did not reach statistical significance. Leptin also inhibited $12 \mathrm{~h}$ food intake of all mice although this did not reach significance for the male WT mice. Total intake $36 \mathrm{~h}$ after injection was significantly lower in male and female leptin-injected mice than in PBS-injected KO mice, although this was due to an increased intake of PBS-injected KO mice, compared with PBS-injected WT mice, rather than an exaggerated leptin response in $\mathrm{KO}$ mice (fig. 3: sex: NS, gene: $p<0.03$, leptin: $p<0.0001$, time: $\mathrm{p}<0.0001$, gene $\times$ leptin $\times$ time: $\mathrm{p}<0.02$ ). There were no longer any differences in food intake of leptininjected $\mathrm{KO}$ mice and their controls $60 \mathrm{~h}$ after the injection (data not shown). 
Fig. 2. Body weight expressed as a percentage of baseline weight (line graphs) and 12 or $36 \mathrm{~h}$ food intake (bar graphs) of mice that received a single third ventricle injection of $1 \mu \mathrm{g}$ of leptin in Experiment 2. Data are means \pm SEM for groups of 8-11 mice. * Significant differences in weight gain of leptin-injected and PBS-injected mice of a specific sex and genotype. Values for food intake that do not share a common superscript are significantly different at $\mathrm{p}<0.05$.

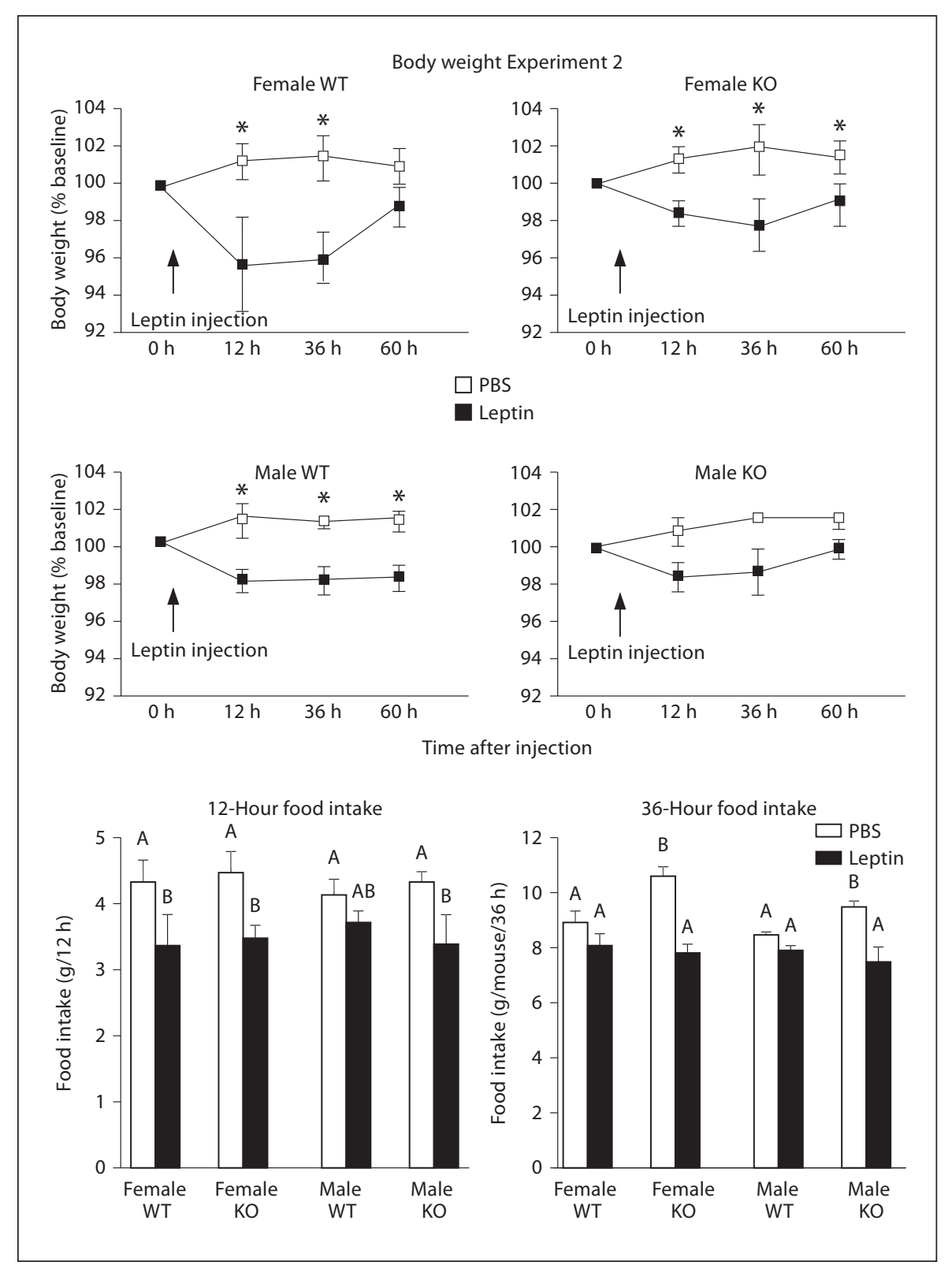

\section{Experiment 3}

This experiment tested the effect of chronic, physiologic doses of leptin on food intake and body composition of the mice. At the end of the experiment, serum leptin was increased by only $50 \%$ in the leptin-infused, compared with PBS-infused mice and there was no effect of sex or genotype on serum leptin concentration (PBS: 3.7 \pm 0.4 , leptin: $5.6 \pm 0.6 \mathrm{ng} / \mathrm{ml}, \mathrm{p}<0.01)$. The leptin infusions significantly inhibited weight gain in female $\mathrm{KO}$ and male KO and WT mice (fig. 3: sex: NS, gene: NS, leptin: $\mathrm{p}<0.0001$, time: $\mathrm{p}<0.0001$, sex $\times$ gene: $\mathrm{p}<0.04$, sex $\times$ time: $p<0.0001$, leptin $\times$ time: $p<0.0001$, sex $\times$ leptin $\times$ time: $\mathrm{p}<0.001$ ). Total food intake during the 12 days of leptin infusion was the same for all mice (fig. 3), but despite the similarity in energy intake, leptin produced a significant reduction of body fat and protein in all treatment groups (table 2: sex: $p<0.02$, gene: NS, leptin: $p<0.0001)$. Leptin also reduced carcass water content of female KO mice (sex: $\mathrm{p}<0.001$, gene: NS, leptin: $\mathrm{p}<0.04$, sex $\times$ gene: $\mathrm{p}<0.04)$ and there was a significant 

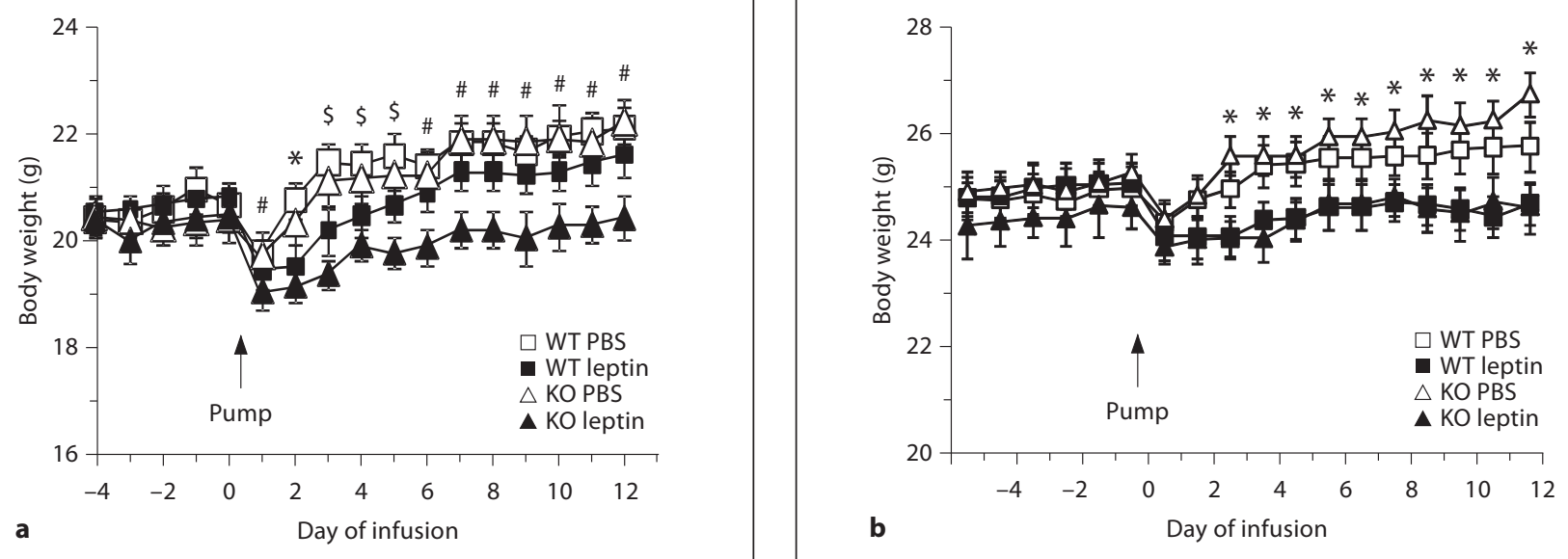

Fig. 3. Daily body weights of female (a) and male mice (b) and total food intake of all of the groups of mice (c) that received continuous intraperitoneal infusions of leptin or PBS for 12 days in Experiment 3. Data are means \pm SEM for groups of 6 or 8 mice. * Significant differences between PBS and leptin infused groups for both WT and KO mice. \$ Significant difference between leptin-treated KO mice and their PBS controls. \# Significant difference between leptin-treated KO mice and both groups of WT mice as well as PBS-treated $\mathrm{KO}$ mice.

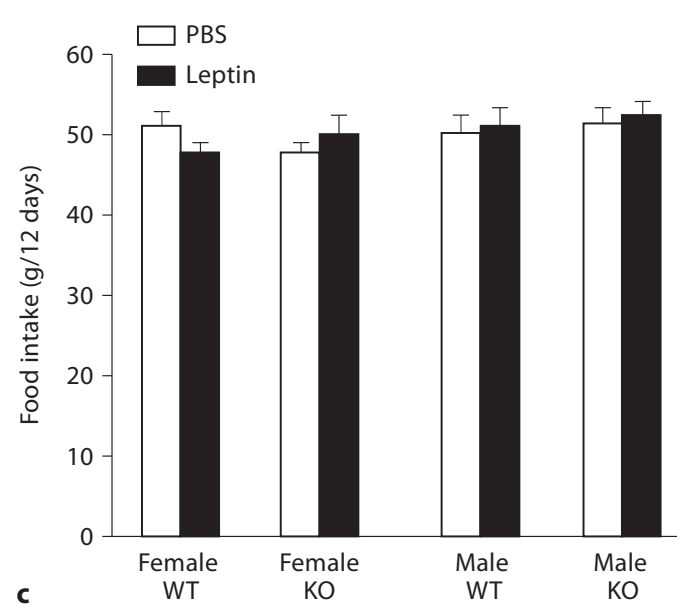

Table 2. Body composition of mice in Experiment 3 (g/mouse)

\begin{tabular}{|c|c|c|c|c|c|}
\hline & Carcass & Fat & Water & Ash & Protein \\
\hline \multicolumn{6}{|l|}{ Females } \\
\hline WT PBS & $19.0 \pm 0.8^{\mathrm{a}}$ & $1.17 \pm 0.07^{\mathrm{a}}$ & $13.1 \pm 0.8^{\mathrm{a}}$ & $0.91 \pm 0.10$ & $3.9 \pm 0.1^{\mathrm{a}}$ \\
\hline WT leptin & $17.8 \pm 0.3^{\mathrm{a}}$ & $0.85 \pm 0.10^{b}$ & $12.7 \pm 0.3^{\mathrm{a}}$ & $0.82 \pm 0.06$ & $3.4 \pm 0.2^{b}$ \\
\hline KO PBS & $18.1 \pm 0.4^{\mathrm{a}}$ & $1.04 \pm 0.08^{\mathrm{a}}$ & $12.4 \pm 0.3^{\mathrm{a}, \mathrm{b}}$ & $0.90 \pm 0.03$ & $3.8 \pm 0.1^{\mathrm{a}}$ \\
\hline KO leptin & $16.4 \pm 0.3^{\mathrm{b}}$ & $0.56 \pm 0.05^{\mathrm{b}}$ & $11.5 \pm 0.2^{\mathrm{a}}$ & $0.94 \pm 0.05$ & $3.4 \pm 0.1^{\mathrm{b}}$ \\
\hline WT leptin & $20.5 \pm 0.4^{\mathrm{a}, \mathrm{b}}$ & $0.76 \pm 0.05^{b}$ & $14.2 \pm 0.3$ & $0.95 \pm 0.04$ & $4.6 \pm 0.1^{b}$ \\
\hline KO PBS & $22.4 \pm 0.4^{\mathrm{a}}$ & $1.34 \pm 0.14^{\mathrm{a}}$ & $15.0 \pm 0.3$ & $0.99 \pm 0.03$ & $5.1 \pm 0.1^{\mathrm{a}}$ \\
\hline KO leptin & $20.3 \pm 0.5^{\mathrm{b}}$ & $0.87 \pm 0.22^{\mathrm{b}}$ & $13.9 \pm 0.3$ & $0.91 \pm 0.01$ & $4.6 \pm 0.1^{\mathrm{b}}$ \\
\hline
\end{tabular}

Data are means \pm SEM for groups of 6 (male KO) or 8 mice sacrificed after 12 days of infusion of either PBS or $10 \mu \mathrm{g}$ leptin/day. Within groups of male or female mice, values for a specific component of body composition that do not share a common superscript are significantly different at $\mathrm{p}<0.05$. 
reduction in lean tissue mass (protein + water) of both male and female KO leptin-treated mice (data not shown: sex: $\mathrm{p}<0.001$, gene: NS, leptin: $\mathrm{p}<0.04)$.

\section{Discussion}

The objective of these studies was to determine the importance of CRHR2 in mediating the effects of leptin on food intake and body composition of mice. The results show that although the procedure used for leptin administration impacts the relative leptin responsiveness of WT and KO mice, expression of CRHR2 is not required for leptin to modify food intake, body weight or body composition. When leptin was given as daily peripheral injections for 3 days, changes in food intake were dependent upon both gender and CRHR2 expression because WT female and $\mathrm{KO}$ male mice responded, whereas WT males and KO females did not. The inhibition of food intake did not, however, correlate with inhibition of weight gain, indicating a significant role for energy expenditure in the animals that did not reduce their food intake. As there was no significant inhibition of weight gain in the mice that did reduce their food intake, this suggests that the thermogenic effects of leptin are more important than inhibition of energy intake in determining body weight of leptin-treated mice. Because leptin caused a significant reduction in food intake of the mice that did not lose weight, none of the animals in this study can be considered totally resistant to peripheral leptin administration.

We have previously reported a gender-related difference in leptin responsiveness of mice [27] and others have reported that leptin receptor number in the hypothalamus changes during the estrous cycle in rats [29]. The estrous cycles of the female mice were not monitored in this study, but it is possible that this influenced the relative leptin responsiveness of the different groups of females because it has been shown that estradiol inhibits, but ovariectomy increases, hypothalamic leptin receptor expression in rats [30]. Thus, hypothalamic leptin receptor expression changes during the estrous even when serum leptin levels do not change [29] and this provides the opportunity for cyclic variability in leptin sensitivity. If the difference in leptin response of female WT versus KO mice was due to them being at different stages of the estrous cycle, it is not clear why the two genotypes would be uniformly following different cycles. In addition, this would not explain the difference in response between the two male genotypes. Although it is possible that measure- ment of food intake only once each day could have missed acute effects of leptin on food intake that resulted from immediate activation of CRHR immediately following leptin administration, this seems unlikely as Gardner et al. [20] found that simultaneous intracerebroventricular injection of leptin and a non-specific CRHR antagonist almost fully reversed the effect of leptin on $14 \mathrm{~h}$ food intake and weight change. It is noteworthy that although peripheral injections of leptin produce very large increases in serum leptin concentration [31], the changes in food intake and body weight of the mice are relatively small. The changes reported here were similar to those reported by others for rats $[12,20]$ and mice [32] receiving peripheral injections of leptin, but suggest that this non-physiologic method of leptin administration is not the most efficient procedure for evaluating the effects of leptin on energy balance.

When leptin was given as a single central injection, food intake and weight gain were inhibited in both groups of female mice. These results imply that the differential changes in food intake and weight gain of female WT and KO mice given peripheral leptin injections may have been associated with differences in leptin transport into the brain, rather than CRHR2 expression having a direct effect on the leptin responsiveness of the mice. The male mice responded to central injections of leptin in a similar manner as to the peripheral injections. Male WT mice showed no significant reduction in food intake, but a significant inhibition of weight gain, whereas the $\mathrm{KO}$ mice significantly reduced their food intake, but weight gain was not different from that in saline-injected controls. In male WT and female WT and KO mice the effect of a single central injection of leptin inhibited weight gain for at least $36 \mathrm{~h}$, whereas the effect of food intake was gone by $36 \mathrm{~h}$ in WT mice, but was still significant in $\mathrm{KO}$ mice. These observations would support the hypothesis that leptin-induced $\mathrm{CRH}$ modifies food intake through a CRHR1-dependent pathway. CRHR1 mediate activation of the HPA axis, stress-induced anxiety and appear to be responsible for an early hypophagia in conditions of stress [14]. CRHR1 are more widely distributed in the hypothalamus than CRHR2 with significant levels of expression present in multiple nuclei including the PVN, ARC and dorsomedial nucleus [15]. Because CRHR2 tend to moderate the effects of CRHR1 activation [33], it is possible that the absence of CRHR2 facilitates an extended hypophagic response to leptin in the $\mathrm{KO}$ mice. This effect was not gender-specific and was therefore unlikely to be associated with the KO mice exhibiting an increased anxiogenic response to the leptin injection because only 
male CRHR2 KO mice show exaggerated anxiety behaviors in either basal or stimulated conditions [33].

By contrast to the varied changes in food intake and weight gain of mice given peripheral or central injections of leptin, chronic peripheral infusion caused a significant reduction of both carcass fat and protein in all of the mice, independent of a change in food intake. The change in serum leptin concentration produced by the low-dose infusion was small and within the physiological range, but was still adequate for a significant effect on body composition, presumably due to a change in energy expenditure or energy partitioning. Peripheral infusions of physiological doses of leptin have been shown to produce a significant increase in VMH CRHR2 mRNA [12]; however, our data suggest that this is not related to leptininduced change in food intake as there was no effect of leptin on food intake in the WT mice that expressed CRHR2 or in the KO mice that did not express any of these receptors.

Other investigators have reported that CRH is one of the neurotransmitters downstream of the leptin receptor that contributes to leptin-induced hypophagia. The results from both in vivo and in vitro studies demonstrate that leptin increases hypothalamic expression $[10,11]$ and release [13] of CRH and that this increase in CRH is independent of activation of the HPA axis. Importantly, it also has been shown that simultaneous injections of leptin and a CRH receptor antagonist prevent leptin-induced hypophagia $[19,20]$. Both of the two major subtypes of the $\mathrm{CRH}$ receptor mediate an inhibition of food intake in response to stress. CRHR1 mediate an immediate, transient inhibition of intake, whereas CRHR2 are associated with an inhibition of food intake that is delayed by about $1 \mathrm{~h}$ after the onset of stress [34]. Observations that leptin increases CRFR2 mRNA in the VMH $[11-12,32]$ led to the suggestion that these receptors are part of a pathway that inhibits food intake of leptin-treated animals $[12,32]$. By contrast, the studies described here indicate that CRHR2 are not required for leptin to inhibit food intake or to change body composition of mice. Therefore, VMH CRHR2 may mediate some other response to changes in leptin status of the animals and antagonism of CRHR1 may account for the blockade of leptin-induced hypophagia by non-specific CRHR antagonists. Recently, Chen et al. [35] reported that injection of Urocortin III, a CRH homologue that has high affinity for CRHR2, into the VMH stimulated ARC POMC expression, inhibited food intake and increased blood glucose concentrations in rats. If the inhibitory effect on food intake was dependent upon ARC POMC, then this would account for normal leptin responsiveness in CRHR2 KO mice because leptin also directly activates ARC POMC neurons [36]. Chen et al. [35] report that activation of VMH CRHR2 caused a rapid increase in plasma glucose concentrations and a potential prevention of hypoglycemia in animals that are in a state of negative energy balance. Thus, it is possible that the leptin-induced increase in VMH CRHR2 is associated with a change in glucose homeostasis.

Although the results of this study indicate that CRHR2 are not required for mice to respond to leptin, there are several factors that need to be considered. The first is that the mice did not express CRHR2 in any tissue and had potentially developed compensatory mechanisms for the absence of these receptors, which could account for the discrepancy between these studies and those that show that non-specific CRHR antagonists prevent a leptin-induced inhibition of food intake $[19,20]$. The second is that the blockade of leptin-induced changes in food intake with non-specific CRHR antagonists may have been mediated by antagonism of CRHR1 receptors $[19,20]$. Finally, many of the studies demonstrating a role for CRH and $\mathrm{CRH}$ receptors in the mediation of leptin-induced changes in energy balance were conducted in rats $[10,19$, $20]$ and it is possible that there are species differences in the response to both leptin and to activation of the CRH system. Despite these limitations the results of the studies described here indicate that CRHR2 are not essential for the effects of leptin on food intake, body weight or body composition. The results do, however, suggest that CRHR2 KO mice have an extended response to central leptin injections compared with their WT controls and that CRHR2 may be required for leptin to promote thermogenesis in male mice because these animals reduced their food intake in response to peripheral and central injections of leptin, but did not lose weight. This genderspecific effect of CRHR2 is consistent with previous reports that anxiety-type behaviors are increased only in male CRHR2 KO mice [33], but that behaviors typical of depression are exaggerated only in females [37].

\section{Acknowledgements}

This work was supported by NIH grant DK-53903 and by Georgia Agricultural Experiment Station grant CSREES/ GEO00932 awarded to R.B.S.H. The author thanks Donna Walker for breeding and genotyping the mice. 


\section{References}

1 Zhang Y, Proenca R, Maffei M, Barone M, Leopold L, Friedman JM: Positional cloning of the mouse obese gene and its human homologue. Nature 1994;372:425-432.

$>2$ Schwartz MW, Seeley RJ: The new biology of body weight regulation. J Am Diet Assoc 1997;97:54-58.

$>3$ Schwartz MW, Seeley RJ, Woods SC, Weigle DS, Campfield LA, Burn P, Baskin DG: Leptin increases hypothalamic pro-opiomelanocortin mRNA expression in the rostral arcuate nucleus. Diabetes 1997;46:21192123.

-4 Myers MG Jr: Leptin receptor signaling and the regulation of mammalian physiology. Recent Prog Horm Res 2004;59:287-304.

$>5$ Elmquist JK, Bjorbaek C, Ahima RS, Flier JS, Saper CB: Distributions of leptin receptor mRNA isoforms in the rat brain. J Comp Neurol 1998;395:535-547.

6 Hayes MR, Skibicka KP, Leichner TM, Guarnieri DJ, DiLeone RJ, Bence KK, Grill HJ: Endogenous leptin signaling in the caudal nucleus tractus solitarius and area postrema is required for energy balance regulation. Cell Metab 2010;11:77-83.

$>7$ Figlewicz DP, Evans SB, Murphy J, Hoen M, Baskin DG: Expression of receptors for insulin and leptin in the ventral tegmental area/ substantia nigra of the rat. Brain Res 2003; 964:107-115.

$>8$ Krahn DD, Gosnell BA, Levine AS, Morley JE: Behavioral effects of corticotropin-releasing factor: localization and characterization of central effects. Brain Res 1988;443: 63-69.

$>9$ Arase K, York DA, Shimizu H, Shargill N, Bray GA: Effects of corticotropin-releasing factor on food intake and brown adipose tissue thermogenesis in rats. Am J Physiol 1988; 255:E255-E259.

-10 Schwartz MW, Seeley RJ, Campfield LA, Burn P, Baskin DG: Identification of targets of leptin action in rat hypothalamus. J Clin Invest 1996;98:1101-1106.

-11 Huang Q, Timofeeva E, Richard D: Regulation of corticotropin-releasing factor and its types 1 and 2 receptors by leptin in rats subjected to treadmill running-induced stress. J Endocrinol 2006;191:179-188.

- 12 Nishiyama M, Makino S, Asaba K, Hashimoto K: Leptin effects on the expression of type-2 CRH receptor mRNA in the ventromedial hypothalamus in the rat. J Neuroendocrinol 1999;11:307-314.

-13 Costa A, Poma A, Martignoni E, Nappi G, Ur E, Grossman A: Stimulation of corticotrophin-releasing hormone release by the obese (ob) gene product, leptin, from hypothalamic explants. Neuroreport 1997;8:1131-1134.

14 Bale TL, Vale WW: CRF and CRF receptors: role in stress responsivity and other behaviors. Annu Rev Pharmacol Toxicol 2004;44: 525-557.
15 Van Pett K, Viau V, Bittencourt JC, Chan RK, Li HY, Arias C, Prins GS, Perrin M, Vale W, Sawchenko PE: Distribution of mRNAs encoding CRF receptors in brain and pituitary of rat and mouse. J Comp Neurol 2000;428: 191-212.

16 Chalmers DT, Lovenberg TW, De Souza EB: Localization of novel corticotropin-releasing factor receptor (CRF2) MRNA expression to specific subcortical nuclei in rat brain: comparison with CRF1 receptor mRNA expression. J Neurosci 1995;15: 6340-6350.

7 Licinio J, Mantzoros C, Negrao AB, Cizza G, Wong ML, Bongiorno PB, Chrousos GP, Karp B, Allen C, Flier JS, et al: Human leptin levels are pulsatile and inversely related to pituitary-adrenal function. Nat Med 1997;3: 575-579.

$>18$ Huang Q, Rivest R, Richard D: Effects of leptin on corticotropin-releasing factor (CRF) synthesis and CRF neuron activation in the paraventricular hypothalamic nucleus of obese (ob/ob) mice. Endocrinology 1998; 139:1524-1532.

19 Uehara Y, Shimizu H, Ohtani K, Sato N, Mori M: Hypothalamic corticotropin-releasing hormone is a mediator of the anorexigenic effect of leptin. Diabetes 1998;47:890893.

20 Gardner JD, Rothwell NJ, Luheshi GN: Leptin affects food intake via CRF-receptormediated pathways. Nat Neurosci 1998;1: 103.

21 Makino S, Nishiyama M, Asaba K, Gold PW, Hashimoto K: Altered expression of type 2 $\mathrm{CRH}$ receptor $\mathrm{mRNA}$ in the VMH by glucocorticoids and starvation. Am J Physiol 1998; 275:R1138-R1145.

22 Turnbull AV, Vale W, Rivier C: Urocortin, a corticotropin-releasing factor-related mammalian peptide, inhibits edema due to thermal injury in rats. Eur J Pharmacol 1996;303: 213-216.

23 Inoue K, Valdez GR, Reyes TM, Reinhardt LE, Tabarin A, Rivier J, Vale WW, Sawchenko PE, Koob GF, Zorrilla EP: Human urocortin II, a selective agonist for the type 2 corticotropin-releasing factor receptor, decreases feeding and drinking in the rat. J Pharmacol Exp Ther 2003;305:385-393.

24 Lewis K, Li C, Perrin MH, Blount A, Kunitake K, Donaldson C, Vaughan J, Reyes TM, Gulyas J, Fischer W, et al: Identification of urocortin iii, an additional member of the corticotropin-releasing factor (CRF) family with high affinity for the CRF2 receptor. Proc Natl Acad Sci USA 2001;98:7570-7575.

25 Chotiwat C, Kelso EW, Harris RB: The effects of repeated restraint stress on energy balance and behavior of mice with selective deletion of CRF receptors. Stress 2010;13: 203-213.
26 Mendoza J, Graff C, Dardente H, Pevet P, Challet E: Feeding cues alter clock gene oscillations and photic responses in the suprachiasmatic nuclei of mice exposed to a light/ dark cycle. J Neurosci 2005;25:1514-1522.

27 Harris RB, Bowen HM, Mitchell TD: Leptin resistance in mice is determined by gender and duration of exposure to high-fat diet. Physiol Behav 2003;78:543-555.

28 Harris RB: Growth measurements in Sprague-Dawley rats fed diets of very low fat concentration. J Nutr 1991;121:1075-1080.

29 Bennett PA, Lindell K, Wilson C, Carlsson LM, Carlsson B, Robinson IC: Cyclical variations in the abundance of leptin receptors, but not in circulating leptin, correlate with NPY expression during the oestrous cycle. Neuroendocrinology 1999;69:417-423.

30 Bennett PA, Lindell K, Karlsson C, Robinson IC, Carlsson LM, Carlsson B: Differential expression and regulation of leptin receptor isoforms in the rat brain: effects of fasting and oestrogen. Neuroendocrinology 1998; 67:29-36.

31 Bowen H, Mitchell TD, Harris RB: Method of leptin dosing, strain, and group housing influence leptin sensitivity in high-fat-fed weanling mice. Am J Physiol 2003;284:R87R100.

-32 Masaki T, Yoshimichi G, Chiba S, Yasuda T, Noguchi H, Kakuma T, Sakata T, Yoshimatsu $\mathrm{H}$ : Corticotropin-releasing hormonemediated pathway of leptin to regulate feeding, adiposity, and uncoupling protein expression in mice. Endocrinology 2003; 144:3547-3554.

33 Bale TL, Contarino A, Smith GW, Chan R, Gold LH, Sawchenko PE, Koob GF, Vale WW, Lee KF: Mice deficient for corticotropin-releasing hormone receptor-2 display anxiety-like behaviour and are hypersensitive to stress. Nat Genet 2000;24:410-414.

34 Sekino A, Ohata H, Mano-Otagiri A, Arai K, Shibasaki T: Both corticotropin-releasing factor receptor type 1 and type 2 are involved in stress-induced inhibition of food intake in rats. Psychopharmacology 2004;176:30-38.

35 Chen P, Vaughan J, Donaldson C, Vale W, Li C: Injection of urocortin 3 into the ventromedial hypothalamus modulates feeding, blood glucose levels, and hypothalamic POMC gene expression but not the HPA axis. Am J Physiol 2010;298:E337-E345.

>36 Cowley MA, Smart JL, Rubinstein M, Cerdan MG, Diano S, Horvath TL, Cone RD, Low MJ: Leptin activates anorexigenic POMC neurons through a neural network in the arcuate nucleus. Nature 2001;411:480484.

37 Bale TL, Vale WW: Increased depressionlike behaviors in corticotropin-releasing factor receptor-2-deficient mice: sexually dichotomous responses. J Neurosci 2003;23: 5295-5301. 
